\title{
Stability in Planktonic Rotifer Assemblages Found in Four Old Diversified Forest Ponds of Eastern Poland
}

\author{
Andrzej Marek Demetraki-Paleolog ${ }^{1 *}$, Joanna Sender², \\ Marcin Kolejko², Radosław Ścibior ${ }^{3}$ \\ ${ }^{1}$ Department of Hydrobiology, University of Life Sciences in Lublin, \\ Dobrzańskiego 37, 20-262 Lublin, Poland \\ ${ }^{2}$ Department of Landscape Ecology and Nature Conservation, University of Life Sciences in Lublin, \\ Dobrzańskiego 37, 20-262 Lublin, Poland \\ ${ }^{3}$ Department of Zoology, Animal Ecology and Wildlife Management, University of Life Sciences in Lublin, \\ Akademicka 13, 20-950 Lublin, Poland
}

Received: 4 May 2017

Accepted: 19 June 2017

\begin{abstract}
One of the most interesting and relatively little known water ecosystems of „Lasy Janowskie” Landscape Park is a group of old ponds which have been excluded from intensive fisheries for many decades. Two of these ponds, belonging to pond complexes, and two other situated outside such complexes were studied in 1996, 2005, 2013 and 2015, regarding their planktonic rotifer assemblages. The total of 65 rotifer taxa were recorded in the plankton. The number of its species in individual reservoirs and years of study ranged from 7 to 21 , and their density was from 29 to 775 ind. $\mathrm{dm}^{-3}$. As many as 25 species in individual ponds and study periods represented dominnats. The present work aimed at determining which of those tiny yet floristically rich ponds were inhabited by more sustainable rotifer assemblages, regarding both their quality and quantity, and to which ecological qualities was such sustainability related to a higher degree; species richness, their diversity, density, biomass, composition or domination structure.. The results of the studies revealed slight variability of ecological properties among the planktonic rorifers in the ponds composing large reservoir groups and a significantly higher variability of these qualities in the „single” ponds which were situated at a long distance from large pond complexes.
\end{abstract}

Keywords: stability, ponds, rotifers

*e-mail: daga@pro.onet.pl 


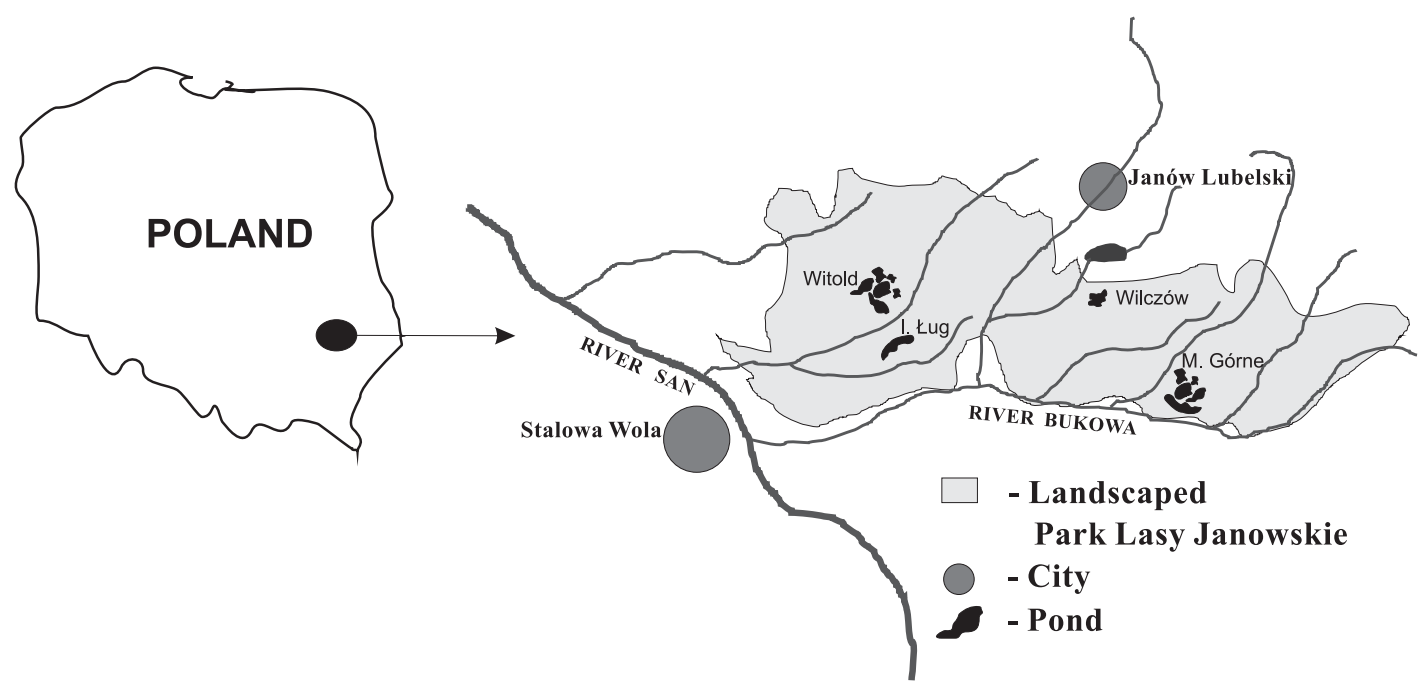

Fig. 1. Map of the study area.

\section{Introduction}

Lasy Janowskie Landscape Park, which covers water and peat bog areas, is rich in tiny water reservoirs. These include significantly diversified ponds, such as the unique Imielty Lug, which is of high scientific value and is protected as a reservation area; the dystrofic ponds of Wilczów and Witols, which are not treated as protected areas; and the large complex of slightly boggy ponds of Momoty Górne [1] (Fig. 1), which remain under the pressure of fisheries.

The rotifers found here provide attractive research material as they become the basic component of tiny zooplankton [2]. Consuming bacteria, algae, protozoa, and dead organic matter, they play a significant role in the trophodynamics of these water ecosystems, and they inhabit them relatively early [3-5]. Many of them react quickly to any changes in water fertility or purity [1, 6-7].

The study was initiated in order to develop the ecological profile of these highly diversified ponds, as well as to determine the dynamics of changes in planktonic rotifer assemblages during a period of 19 years. The work aimed at defining the degree of sustainability among planktonic rotifer assemblages inhabiting the ponds of Lasy Janowskie Landscape Park, to see if their sustainability was similar in all the analyzed reservoirs and if it referred to all or only to some of the ecological qualities of rotifer assemblages.

\section{Study Area}

Lasy Janowskie Landscape Park, situated on Rownina Bilgorajska (Bilgoraj Plain) in southeastern Poland, was founded in 1978. It covers a large woodland area dominated by pine forests $(85 \%)$ and includes a dense network of rivers, canals, and ditches [1]. There are vast swamps and peat-bogs here, as well as groups of morphologically diversified ponds (Fig. 1).

Two of the four reservoirs studied, namely the dystrophic pond called Witold and the eutrophic pond of Momoty Gorne remaining under fishery pressure, are

Table 1. Physical and chemical parameters of water in Lasy Janowskie Landscape Park ponds. The mean values from four periods (spring and summer 1996 plus spring and summer 2005) were taken for analysis.

\begin{tabular}{|c|c|c|c|c|}
\hline \multirow{2}{*}{ Parameter of water } & \multicolumn{4}{|c|}{ PONDS } \\
\hline & Witold & Wilczów & Imielty Ług & Momoty Górne \\
\hline Temperature ${ }^{\circ} \mathrm{C}$ & $21.5 \pm 1.8$ & $22.3 \pm 2.1$ & $21.8 \pm 1.7$ & $20.9 \pm 1.8$ \\
\hline $\mathrm{pH}$ & $6.88 \pm 0.11$ & $5.80 \pm 0.28$ & $6.79 \pm 0.07$ & $7.05 \pm 1.10$ \\
\hline Conductivity $\mu \mathrm{S} \mathrm{cm}^{-2}$ & $185.0 \pm 18.1$ & $123.0 \pm 15.9$ & $126.0 \pm 22.8$ & $587.0 \pm 98.2$ \\
\hline $\mathrm{O}_{2} \mathrm{mg} \mathrm{dm}^{-3}$ & $8.3 \pm 2.2$ & $7.6 \pm 1.8$ & $7.9 \pm 2.1$ & $9.3 \pm 3.1$ \\
\hline $\mathrm{P}-\mathrm{PO}_{4} \mathrm{mg} \mathrm{dm}{ }^{-3}$ & $0.005 \pm 0.003$ & $0.026 \pm 0.021$ & $0.026 \pm 0.019$ & $0.019 \pm 0.011$ \\
\hline Total P mg dm ${ }^{-3}$ & $0.105 \pm 0.11$ & $0.055 \pm 0.28$ & $0.235 \pm 0.07$ & $0.095 \pm 1.10$ \\
\hline $\mathrm{N}-\mathrm{NO}_{3} \mathrm{mg} \mathrm{dm}^{-3}$ & $0.105 \pm 0.038$ & $0.105 \pm 0.045$ & $0.282 \pm 0.089$ & $0.305 \pm 0.099$ \\
\hline $\mathrm{N}-\mathrm{NH}_{4} \mathrm{mg} \mathrm{dm}^{-3}$ & $0.326 \pm 0.120$ & $0.364 \pm 0.151$ & $0.576 \pm 0.089$ & $0.185 \pm 0.023$ \\
\hline
\end{tabular}


Table 2. Plant associations occurring in studied ponds of Lasy Janowskie Landscape Park $(+-$ rare, $1<5 \%, 2=5-25 \%, 3=26-50 \%, 4$ $=51-75 \%$, and $5=76-100 \%$ ) in 1996 and 2005 .

\begin{tabular}{|c|c|c|c|c|}
\hline Plant associations & Witold & Wilczów & Imielty Ług & $\begin{array}{l}\text { Momoty } \\
\text { Górne }\end{array}$ \\
\hline \multicolumn{5}{|c|}{ Floating plants (pleustonic) } \\
\hline Lemno minoris-Salvinietum natantis (Slavnić 1956) Korneck 1959 & 1 & + & + & 1 \\
\hline $\begin{array}{c}\text { Spirodeletum polyrhizae (Kelhofer 1954) W.Koch } 1954 \text { em. R.Tx. et } \\
\text { A.Schwabe } 1974 \text { in R.Tx. } 1974\end{array}$ & 1 & + & & + \\
\hline Lemnetum gibbae Miy. et J.Tx. 1960 & & & + & 1 \\
\hline \multicolumn{5}{|c|}{ Plants with floating leaves (nympheids) } \\
\hline Nupharo-Nymphaeetum albae Tomasz. 1977 & 2 & & 1 & 2 \\
\hline Potametum natantis Soó 1923 & 1 & & 1 & 2 \\
\hline Polygonetum natantis Soó 1927 & & 1 & & + \\
\hline \multicolumn{5}{|c|}{ Submerged macrophytes (elodeids) } \\
\hline Potametum compressi Tomasz. 1978 & & & 1 & \\
\hline Elodeetum canadensis (Pign. 1953) Pass. 1964 & & 1 & & \\
\hline Ceratophylletum demersi Hild 1956 & 2 & 1 & 1 & 3 \\
\hline Potametum perfoliati Koch 1926 em. Pass. 1964 & 1 & & & 1 \\
\hline Potametum pectinati Carstensen 1955 & + & + & & 1 \\
\hline \multicolumn{5}{|c|}{ Emergent macrophytes (helophytes) } \\
\hline Scirpetum lacustris (Allorge 1922) Chouard 1924 & 1 & 1 & + & 1 \\
\hline Phragmitetum australis (Gams 1927) Schmale 1939 & 4 & 3 & 3 & 5 \\
\hline Typhetum angustifoliae (Allorge 1922) Soó 1927 & 4 & & 3 & 3 \\
\hline Typhetum latifoliae Soó 1927 & 2 & 1 & 1 & 3 \\
\hline Sparganietum erecti Roll 1938 & & & 1 & 1 \\
\hline Glycerietum maximae Hueck 1931 & 1 & 1 & & 2 \\
\hline Thelypteridi-Phragmitetum Kuiper 1957 & 2 & & 2 & 3 \\
\hline Total & 13 & 10 & 11 & 16 \\
\hline
\end{tabular}

reservoirs composing large pond complexes covering areas of 89 ha and 129 ha, respectively. On the other hand, the unique Imielty Lug Pond, covered by reservation protection law, and Wilczow Pond, not protected, are large, single, dystrophic reservoirs, not included in any complexes, with an area of ca. 50 ha each [1]. For many years the reservoirs were excluded from fisheries. Their waters are characterized by low mineralization, acidic reaction (with the exception of Momoty Górne), high levels of organic matter concentration, and low oxygenation (Table 1).

Morphologically, the ponds resemble natural reservoirs with well-developed litoral. They are inhabited by a total of 18 plant associations. The majority of these, as many as 16 , occurred in Momoty Górne pond, while the lowest number, 10, was recorded in Witold. They were dominated by emergent plant associations, including seven assemblages with the most abundant Phragmitetum australis. The least common were the associations of plants with floating leaves, as well as pleustinic plants at three assemblages of each (Table 2).

The association most abundantly represented among the submerged macrophytes was Ceratophylletum demersi. The plants in the analyzed ponds were distributed mosaic-like. Phytolitoral was developing irregularly, covering nearly their whole area. The majority of plant species composing the phytocenoses mentioned here occurred in Momoty Górne and Witold ponds, amounting to 54 and 55, respectively. The ponds of Wilczów and Imielty Ług revealed a similar number of species, 34 and 35 , respectively. The least numerous group was formed by pleustophytes, while the largest one was composed of helophytes.

The dykes of the analyzed ponds are very wide, with gently sloping edges, and they are typically covered by shrubs and bushes, sometimes even by woods. It is only 
at the complex of Momoty Gorne ponds that intensive fisheries had been initiated long before the study started. The catchment areas of these ponds include dykes, reeds, swamps, peat-bogs, trees, shrubs, and the dominating woodland areas.

\section{Materials and Methods}

The biological material was sampled in the spring and autumn of 1996, 2005, 2013, and 2015. The study included four ponds. In each of them and at each period the plankton was sieved in three replications. The samples were collected by taking $10 \mathrm{dm}^{3}$ of water with the use of a Ton II sampler at a depth of $0.5 \mathrm{~m}$. The water collected in this way was sieved through a planktonic net No. 25 and condensed to a constant volume of $100 \mathrm{~cm}^{3}$. The samples were preserved with Lugol's liquid and 4\% formaldehyde and glycerine solution. The samples were used to determine the species and abundance of rotifers. In order to verify the regularity of all the variables we used the Shapiro-Wilk test. The significance of differences in the density and biomass of rotifers among individual reservoirs and study periods was studied with the use of Kruskal-Wallis non-parametric rang ANOVA test in SAS. The similarity of rotifer communities studied in the individual ecosysytems and study periods was determined by means of the Jaccard index with the cluster method using Multi Variate Statistical Package (MVSP v. 3.1). The analysis of similarities was performed with the help of Unweighted Pair-Group Method Using Arithmetic Avarages (UPGMA). To interpret the results we calculated the index of rotifer domination and determined the sustainability of domination structure [8]. Wet biomass of planktonic rotifers was calculated in WW $\mu \mathrm{g} \mathrm{dm}^{-3}[9]$ and Shannon index was identified.

We determined physical and chemical agents out in spring and autumn 1996 and 2005, following methodology in [10-11]. Studies were carried out in 1996 and 2005. We recorded all species among four groups of macrophytes (emergent, floating-leaved, submerged, and floating plants). Nomenclature for aquatic macrophytes followed [12]. Aquatic plants were grouped into five classes $(+=$ rare, $1<5 \%, 2=5-25 \%, 3=26-50 \%, 4=51-75 \%$, and $5=76-100 \%$ ) following the phytosociological approach [13]. Trophic status of the ponds was determined according to Paleolog et al. [1].

\section{Results and Discussion}

The density of rotifer plankton was rather low and charactersitic of poor and medium-fertile waters. Its highest values of 573 and 775 ind. $\mathrm{dm}^{-3}$ were recorded in the ponds of Wilczow and Imielty Lug in 1996. In the following years these values were much lower and more stable, as they ranged from 29 to 33 ind. $\mathrm{dm}^{-3}$ in Wilczów and from 49 to 82 in Imielty Ług (Fig. 2).

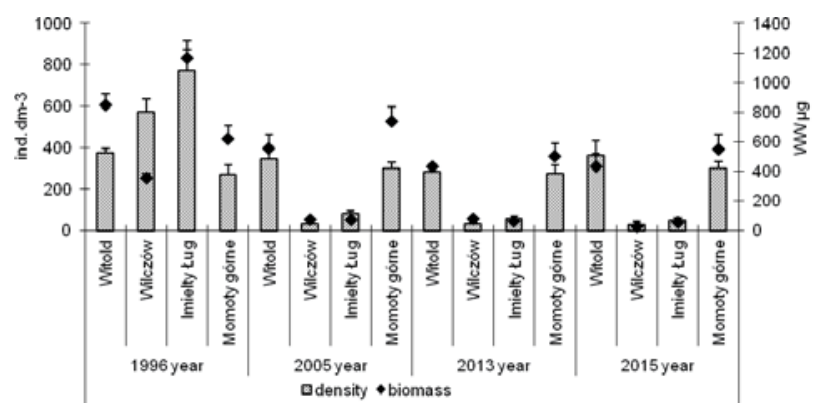

Fig. 2. Planktonic rotifer density and wet biomass (+SD) in the ponds of Lasy Janowskie Landscape Park of in 1996, 2005, 2013, and 2015.

In the ponds composing larger water complexes, namely Witold and Momoty Gorne, the number of planktonic rotifers was much more stable and ranged from 272 to 374 ind. $\mathrm{dm}^{-3}$ (Fig. 2). A similarly low density of planktonic rotifers was recorded in other reservoirs of this type [14-16]. In the majority of other ponds, however, higher or much higher rotifer density was observed by the authors [12, 17-18]. Differences in rotifer density observed in ponds in different years of the study are statistically significant, except for the differences in density noted in Momoty Gorne and in Witold between 2005, 2013, and 2015, and in Wilczów between 2005 and 2013.

The biomass of planktonic rotifers in the studied ponds was in most cases insignificant and its value was similar at a comparable level of stability, significance, and abundance (Fig. 2).

For the sake of comparison, three ponds of Poleski National Park, which, unlike the landscape park ponds, are not of dystrophic character, revealing lower fluctuations in the abundance of planktonic rotifers in time. The biomass of planktonic rotifers, similar to that in the park ponds, was a value changing more significantly in time [19].

Numerous authors have claimed that species composition of plankton may be significantly variable, yet the biomass remains stable. It should be noted, however, that the majority of such opinions is based on studying phytoplankton rather than zooplankton [20-21].

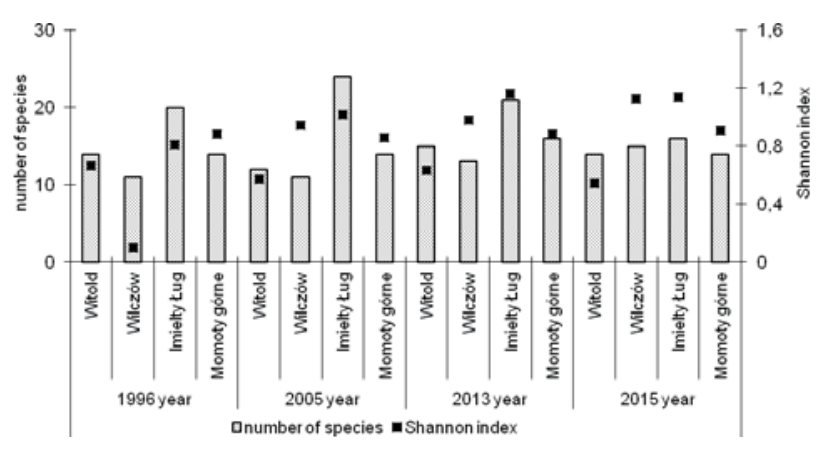

Fig. 3. Number of species and Shannon index for planktonic rotifers in the ponds of Lasy Janowskie Landscape Park in 1996, 2005, 2013, and 2015. 
Table 3. Domination structure of planktonic rotifers (\%) in the ponds of Lasy Janowskie Landscape Park in 1996, 2005, 2013 , and 2015.

\begin{tabular}{|c|c|c|c|c|c|c|c|c|c|c|c|c|c|c|c|c|}
\hline Year & \multicolumn{4}{|c|}{1996} & \multicolumn{4}{|c|}{2005} & \multicolumn{4}{|c|}{2013} & \multicolumn{4}{|c|}{2015} \\
\hline Ponds & $\frac{\sum}{0}$ & 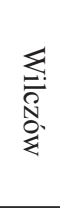 & 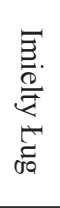 & 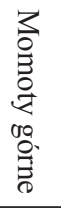 & $\frac{\sum}{\frac{0}{2}}$ & 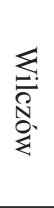 & 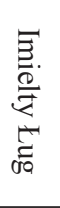 & 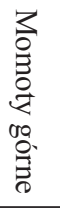 & $\frac{\sum}{\stackrel{0}{2}}$ & 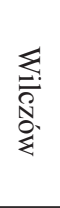 & 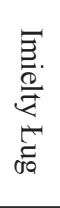 & 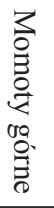 & $\frac{\sum}{\frac{0}{2}}$ & 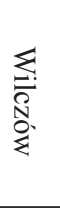 & 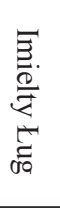 & 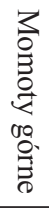 \\
\hline Dominants & & & & & & & & & & & & & & & & \\
\hline Anuraeopsis fissa Gosse & & & & & & & & & & & & & & 10 & & \\
\hline Asplanchna multiceps (Schrank) & & & & & & & & & & 21 & & & & & & \\
\hline Asplanchna priodonta Gosse & 9 & & & 9 & & & & 10 & & & & & & & & \\
\hline Asplanchna sieboldi (Leydig) & & & & & & 13 & & & & & & & & & & \\
\hline Bdelloidea non. det. & & & & & & 9 & & & & & & & & & & \\
\hline Brachionus angularis Gosse & & & & 17 & & & & 20 & & 12 & & 14 & & & & 15 \\
\hline Brachionus diversicornis (Daday) & 11 & & & & 10 & & & & 19 & & 11 & & 8 & & & \\
\hline Brachionus quadridentatus Herm. & & & & & & & & & & 12 & & & & & & \\
\hline Collotheca ambigua (Hudson) & & & & & & & & & & 9 & & & & & & \\
\hline Colurella colurus (Ehrb.) & & & & & & 22 & & & & & 9 & & & & 10 & \\
\hline Conochilus unicornis Rouss. & 14 & 96 & & 19 & 7 & & & 11 & & & & 10 & & & & 9 \\
\hline Euchlanis deflexa Gosse & & & & & & 16 & & & & & & & & & & \\
\hline Euchlanis dapidula Parise & & & & & & & & & & & 7 & & & & & \\
\hline Euchlanis lyra Hudson & & & & & & 9 & & & & & & & & & & \\
\hline Gastropus stylifer Imhof & & & 22 & & & & & & & & & & & & & \\
\hline Kellicottia longispina (Kell.) & & & & & & 9 & & & & & 9 & & & 14 & & \\
\hline Keratella cochlearis (Gosse) & 55 & & 45 & 24 & 65 & & 11 & 30 & 57 & & 21 & 33 & 69 & & 10 & 32 \\
\hline Keratella quadrata (Müll.) & & & & 8 & & & & & & & & 14 & & & & \\
\hline Lecane crenata Harr. & & & & & & & & & & 12 & & & & & & \\
\hline Lecane quadridentata (Ehrb.) & & & & & & & & & & 9 & & & & & & \\
\hline Lepadella rhomboides (Gosse) & & & & & & & & & & & & & & & 8 & \\
\hline Mytilina crassipes (Lucks) & & & & & & & 7 & & & & & & & & & \\
\hline Mytilina mucronata (Müll.) & & & & & & & & & & & & & & 10 & & \\
\hline Polyarthra euryptera Wierz. & & & & & & & 38 & & & & & & & & 10 & \\
\hline Polyarthra vulgaris Carl. & & & & 14 & & & & 14 & & & & 10 & & & 16 & 14 \\
\hline Testudinella patina (And. et Shep.) & & & & & & & & & & & & & & 10 & & \\
\hline Subdominants & 7 & 1 & 29 & 8 & 16 & 22 & 44 & 13 & 20 & 24 & 44 & 18 & 19 & 55 & 45 & 28 \\
\hline Recedents & 3.7 & 2.6 & 4.1 & 1.8 & 2.0 & 0.0 & 0.0 & 2.3 & 3.2 & 0.0 & 0.0 & 1.8 & 3.9 & 0.0 & 0.0 & 2 \\
\hline
\end{tabular}

The four ponds studied revealed the presence of 65 rotifer taxa. Their highest abundance, 57 species, was noted at the site belonging to the reservation area, the dystrophic pond of Imielty Lug. Another dystrophic pond of Wilczow revealed only 34 taxa, while the reservoirs forming larger pond complexes, Witold and Momoty Gorne, were inhabited by 19 and 18 species, respectively, during the whole study period. In comparison, other ponds in Europe and all over the world have revealed in most cases similar species abundance [2, 22-25] or lower numbers [4, 17, 26-27]. Species abundance of rotifers in the four analyzed ponds was a stable value, as it remained at a similar level during all the periods analyzed here. Its highest values were always recorded in the pond of Imielty Lug (16 to 21 species), while the lowest numbers were noted in Wilczow (7 to 11 species, except for 2015, 
when 15 species were observed). In the ponds belonging to larger reservoir complexes, namely the ponds of Witold and Momoty Gorne, the number of taxa remained within an even smaller range of 12 to 14 species (Fig. 3).

Species diversity expressed with the Shannon index was slightly different than species abundance. In the Imielty Lug pond the former reached high values after 2005, yet earlier it was slightly lower than in the Momoty Gorne pond (Fig. 3). In Wilczow, the Shannon index and species abundance were initially low, yet in 2005 and in later years the index was at a significantly higher level and reached values even higher than in the remaining ponds analyzed here. It may thus be concluded that, except for the pond of Wilczow, the Shannon index during all the study periods was a stable value, fluctuating within a narrow range (Fig. 3). The literature does not offer many references regarding long-term stability of the Shannon index calculated for rotifers inhabiting the ponds of other regions in Poland and Europe. To compare, three ponds of Poleski National Park, which, unlike the ponds of the landscape park, did not have dystrophic character, revealing much higher differences regarding their species richness [19].

Among the dominants of these small reservoirs, as many as 25 species of rotifers were found (38\% of all the species identified). Many of them are common species (Table 3).

Despite such a high number of dominant species, the sustainable domination structure was observed only in the Momoty Gorne pond. The situation of balanced dominant structure was recorded there during all the study periods. In the remaining ponds during all the study periods the dominant structure was not balanced (Table 3). The criterion of the degree of domination sustainability among rotifers was adopted after Bielańska-Grajner [8]. The author treats an assemblage as sustainable when it includes all three classes of domination (dominants, subdominants, and recedents), and at least three of the species belong to dominants and none of them exceeds the $45 \%$ share of their total abundance.
In order to analyze the degree of modifications occurring in time, regarding the species' composition and domination structure in the particular reservoirs the Serensen index was calculated to show the degree of faunistic similarity of different rotifer communities (Fig. 4).

The cluster method revealed a very high similarity among rotifer communities inhabiting the Witold pond. The Serensen index determining similarity of rotifer communities in this particular pond ranged at a very high level, from 0.79 to 0.92 . Also, a group of clear faunistic similarities was observed among rotifer assemblages inhabiting Momoty Gorne in different years. Serensen's index in this particular pond ranged from 0.74 to 0.94 (Fig. 4) in the years compared here. Such low dynamics of changeability within the communities of small plankton may result from the nature of Witold and Momoty Gorne. Both reservoirs, unlike the remaining ones, belong to larger pond complexes. To compare, similarly low changeability in plankton communities in a long-term period was also observed in large water-reservoir complexes of Poleski National Park in southeastern Poland [19].

The dynamics of rotifer communities in the two remaining landscape park ponds (not belonging to large water complexes) looked different. Rotifer communities observed there were significantly different from groups inhabiting the same reservoirs at a different time. The Serensen index defining similarity between rotifer communities in different years in the Wilczow pond amounted to as little as $0.18-0.24$, while the value for Imielty Lug ranged from 0.18 to 0.28 (Fig. 4).

Many authors claim that lower rotifer community sustainability is related to their poor species diversity [28]. The present studies on planktonic rotifers have not quite confirmed this opinion, as the lowest mean values of the Shannon index were recorded in Witold and Wilczow ponds ( 0.60 and 0.69 , respectively), while the highest values were noted in Imielty Lug and Momoty Gorne (1.03 and 0.88 , respectively). The highest sustainability of

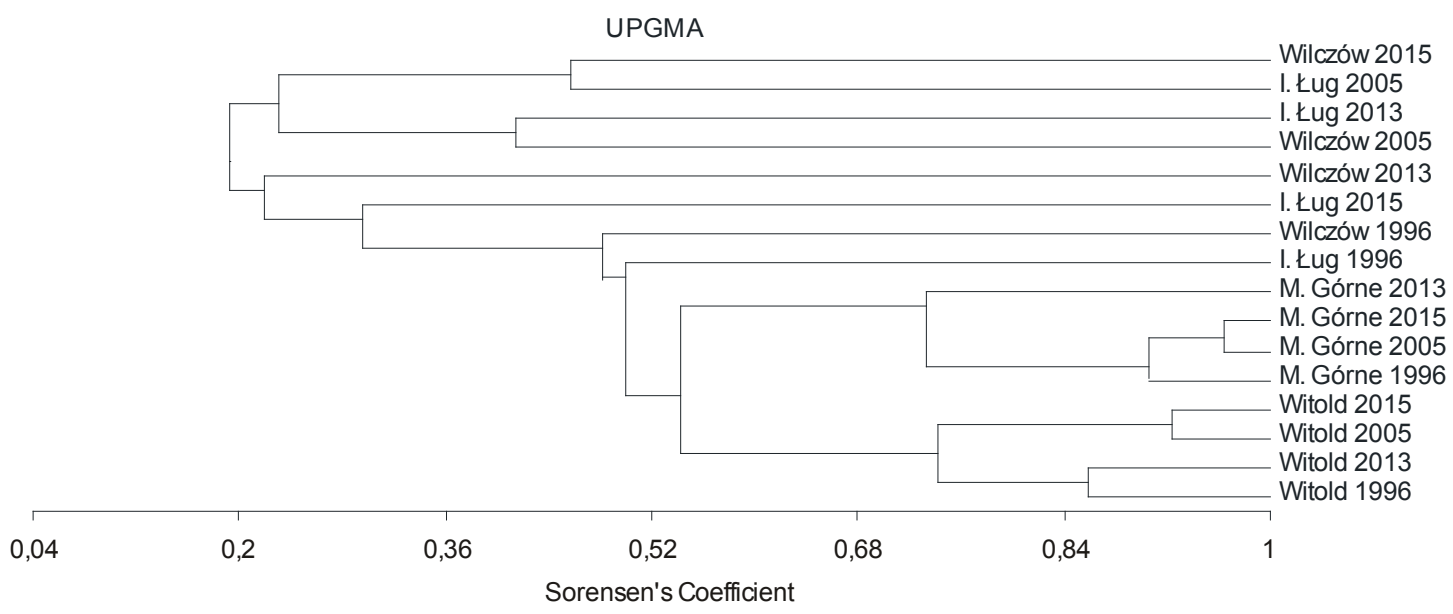

Fig. 4. Similarity structure of planktonic rotifer assemblages based on their quantity composition in Lasy Janowskie Landscape Park ponds in 1996, 2005, 2013, and 2015. 
rotifer assemblages in time was observed in Witold and Momoty ponds, while its much lower value was observed in Wilczow and Imielty Lug. Similar studies performed in other Polish ponds and at a different times proved, however, that higher species diversity among rotifers may be related to higher sustainability of their communities [19].

The reason for high sustainability of rotifer assemblages in Witold and Momoty Gorne ponds could also be their situation in large water complexes. Howeth Jenifer and Leibold Matthew [26] also claim that that the degree of sustainabilty may be determined by the rate of species spread among a local assemblage. The authors quote the example of a complex of closely situated ponds as the habitat for more stable meta-populations, and explain that a meta-population consists of numerous local assemblages, which offers more chance for stabilizing migrations. This suggests that higher sustainability of rotifer communities (and thus preservation of their species diversity and conservation of rare species) is fostered by biocenoses, including numerous meta-populations. Such a regularity among other hydrobionts is also mentioned in other studies [20, 29].

\section{Conclusions}

The analyzed ponds of Lasy Janowskie Landscape Park constitute valuable - often dystrophic - ecosystems of tiny water reservoirs situated in woodlands. They are not typically highly dominated by single species. The dominants include numerous but not necessarily common species. The low density of planktonic rotifers distinguishes these particular reservoirs from the majority of fish-breeding ponds. The studies revealed that:

1. There was little changeability in time regarding both species abundance and species diversity.

2. Sustainability of rotifer assemblages in the of Lasy Janowskie Landscape Park ponds is not clearly related to the degree of species diversity.

3. Planktonic rotifer assemblages were definitely more changeable in time in those reservoirs that were not situated within the area of large pond complexes.

4. Modifications regarding the biomass and abundance of planktonic rotifers in time varied, yet they were slightly more stable in the ponds belonging to large water complexes.

5. The degree of stability of the organisms creating the pond biocenosis may be useful in assessing the ecological status of the studied reservoir.

\section{References}

1. PALEOLOG A., RADWAN S., KOWALCZYK W., KOWALIK C., STRYJECKI R., ZWOLSKI W. Water invertebrate fauna of „Lasy Janowskie” Landscape Park. [In:] S. Radwan (Ed.) Natural environment of "Lasy Janowskie" Landscape Park. UMCS Press. 117-133, 1997 [In Polish].
2. SHARMA B.K. Zooplankton diversity of Loktak Lake, Manipur, India. Journal of Threatened Taxa, 3/5, 1745, 2011.

3. FRISCH D., COTTENIE K., BADOSA A., GREEN A. J. Strong spatial influence on colonization rates in a pioneer zooplankton metacommunity. PloS one, 7 (7), e40205, 2012.

4. SAHUQUILLO M., MARIA ROSA M. Crustacean and rotifer seasonality in a Mediterranean temporary pond with high biodiversity (Lavajo de Abajo de Sinarcas, Eastern Spain). Limnetica 1 (29), 75, 2010.

5. LI LI CUIJUAN NIU, RUI MA. Rapid temporal succession identified by COI of the rotifer Brachionus calyciflorus Pallas in Xihai Pond, Beijing, China, in relation to ecological traits. Journal of plankton research 32 (6), 951, 2010.

6. EJSMONT-KARABIN J. The usefulness of zooplankton as lake ecosystem indicators: rotifer trophic state index. Pol. J. Ecol, 60 (2), 339, 2012.

7. SHARMA B.K., DUDANI V.K. Rotifers from some tropical ponds in Bihar: species composition, similarities and trophic indicators. Journal of the Indian Institute of Science, 72 (2), 121, 2013.

8. BIELAŃSKA-GRAJNER I. Psammon rotifers of water reservoirs of some areas of Poland. University of Silesia Publishing, 1, 2005 [In Polish].

9. EJSMONT-KARABIN J. Empirical equations for biomass calculation of planktonic rotifers. Pol. Arch. Hydrobiol. 45, 513, 1998.

10. GOLTERMAN H.L. Methods for Chemical Analysis of Fresh Waters. IBP Handbook No 8, Oxford and Edinburg: $1,1971$.

11. HERMANOWICZ W., DOŻAŃSKA W., DOJLIDO J., KOZIOROWSKI B. Physical and chemical analyses of water and sewage. Arkady, Warszawa: 1, 1976 [In Polish].

12. MATUSZKIEWICZ W. Guide for the determination of plant communities in Poland. Warszawa PWN, 2008 [In Polish].

13. BRAUN-BLANQUET J. Pflanzensoziologie. 3 Aufl. Springer, Vienna, 1976.

14. DEMETRAKI-PALEOLOG A. Planktonic rotifers communities of different types of peat-bog reservoirs and wetlands of Poleski National Park (Eastern Poland). Teka Komisji Ochrony i Kształtowania Środowiska Przyrodniczego. 7, 67, 2010.

15. VAN METER ROBIN J., CHRISTOPHER M. SWAN JOEL W. Salinization alters ecosystem structure in urban stormwater detention ponds. Urban Ecosystems 14 (4), 723, 2011.

16. GILBERT J.J., DIEGUEZ M.C. Low crowding threshold for induction of sexual reproduction and diapause in a Patagonian rotifer. Freshwater Biology, 55 (8), 1705, 2010.

17. SULEHRIA A.Q.K., MUSHTAQ R., EJAZ M. Abundance and composition of Rotiferes in a pond near balloki headworks. Jurnal of Animal and Plant Sciences, 22, 4, 1065, 2012.

18. DE BACKER S., TEISSIER S., TRIEST L. Stabilizing the clear-water state in eutrophic ponds after biomanipulation: submerged vegetation versus fish recolonization. Hydrobiol ogia, 689 (1), 161, 2012.

19. DEMETRAKI-PALEOLOG A. Studies on sustainability of planktonic rotifer assemblages in select national park ponds and wetland reservoirs. Polish Journal of Environmental Studies, 23 (1), 51, 2014.

20. HOWETH JENIFER G., LEIBOLD MATHEW A. Species dispersal rates alter diversity and ecosystem stability in pond metacommunities. Ecology. 91 (9), 2727, 2010. 
21. JOCHIMSEN M.C., KÜMMERLIN R. Compensatory dynamics and the stability of phytoplankton biomass during four decades of eutrophication and oligotrophication. Ecology letters. 16 (1), 81, 2013.

22. DIAZ-PANIAGUA C., FERMANDEZ-RAMUDIO R., FLORENCIO M., GARCIA-MURILLO P., GÓMEZRODRIGUEZ C., PORTHEAULT A., SILIASTRÖM P. Temporay ponds from Doñana National Park: a system of natural habitats for the preservation of aquatic flora and fauna. Limnetica, 29 (1), 41, 2010.

23. ALTERMATT F., SCHREIBER S., HOLYOAK M. Interactive effects of disturbance and dispersal directionality on species richness and composition in metacommunities. Ecology, 92 (4), 859, 2011.

24. SKOWRONEK E., CUDAK A., BIELAŃSKA-GRAJNER I. Effect of Recreation on the Species Richness and Diversity of Rotifers in Ponds. Journal of Water Resource and Protection. 4 (9), 795, 2012.

25. TAYADE S.N. Population dynamics of rotifers in ephemeral ponds. Journal of Global Biosciences ISSN. 2 (4), 71, 2013.
26. DIAZ-PANIAGUA C., FERMANDEZ-RAMUDIO R., FLORENCIO M., GARCIA-MURILLO P., GÓMEZRODRIGUEZ C., PORTHEAULT A., SILIASTRÖM P. Temporay ponds from Doñana National Park: a system of natural habitats for the preservation of aquatic flora and fauna. Limnetica, 29 (1), 41, 2010.

27. LLEÓON D., PENALVER P., CASAS J., JUAN M., FUENTES F., GALLEGO I., TOJA J. Zooplankton richness in farm ponds of Andalusia (southern Spain). A comparison with natural wetlands. Limnetica, 1 (29), 153. 2010.

28. NIESLER A. 2001. Changes in seston assemblages of rotifers found in Nieiotka torrent below water downflow from a forest pond. Arch. Ochr. Środow. 27 (4), 129, 2001 [In Polish].

29. PINSKY M.L. Can habitat patchiness explain whether marine populations are open or closed Lessons from metapopulation theory. In: The $95^{\text {th }}$ ESA Annual Meeting, 2010. 